\title{
A study on the bond behavior of different FRCM systems
}

\author{
Adel Younis ${ }^{1 *}$, and Usama Ebead $^{2}$ \\ ${ }^{1} \mathrm{PhD}$ candidate, Department of Civil and Architectural Engineering, College of Engineering, Qatar University, Doha, Qatar \\ ${ }^{2}$ Professor, Department of Civil and Architectural Engineering, College of Engineering, Qatar University, Doha, Qatar
}

\begin{abstract}
Fabric-reinforced cementitous matrix (FRCM) composites are usually applied on the concrete surface for the purpose of strengthening reinforced concrete structures. However, the efficiency of FRCM strengthening is notably affected by the bond between the FRCM system and concrete substrate. In view of that, the current paper presents the results of a preliminary experimental study carried out to investigate the bond characteristics between FRCM composites and concrete. Six number of specimens, each consisted of a $150-\mathrm{mm}$ concrete cube with a double-shear connection to an FRCM system, were subjected to direct-shear loading test. The parameters investigated include (a) FRCM material (carbon, polyparaphenylene benzobisoxazole (PBO), and glass); and (b) Bond length ( $75 \mathrm{~mm}$ or $100 \mathrm{~mm}$ ). The FRCM systems typically included a single layer of fabric with the associated mortar, and the bond width was uniformly taken as $100 \mathrm{~mm}$. The test results revealed that the bond capacity is enhanced with an increase in the FRCM bonded length. The PBO-FRCM showed the highest bond capacity between FRCM composite and concrete substrate among the three systems. The modes of failure observed in carbon-, PBO-, and glass-FRCM bond tests are fabric delamination, FRCM mortar/concrete debonding, and fabric rapture, respectively. The PBO- and glass-FRCM bond tests thus exhibited a more brittle behavior at failure than that of the carbon-FRCM counterpart.
\end{abstract}

\section{Introduction}

Fabric reinforced cementitious matrix (FRCM) is composed of dry fibres embedded in an inorganic matrix, which is surface-applied for strengthening reinforced concrete (RC) and masonry structures [1]. FRCM systems have recently emerged as a more feasible solution for structural rehabilitation and repair as compared to the well-established, now obsolete, ferrocement [2] and the commonly used fibre-reinforced polymer (FRP) [3-7] strengthening techniques. In all likelihood, such a growing interest in the FRCM strengthening technique is attributed to a number of advantages associated with it such as the ability to resist extremely high temperatures, the possibility to use recycled materials, and the use of cement-based mortar as a binding agent which is wellmatched with the original concrete substrate [8].

Successful applications of FRCM system for strengthening $\mathrm{RC}$ structures were reported in previous studies including RC slabs [9], columns [10,11], and beams critical in flexure [12,13] or in shear [14-17]. In these studies, a considerable improvement was generally reported in the structural capacity of the FRCMstrengthened members compared to that of the nonstrengthened reference. Nonetheless, it is well-agreed that a sufficient understanding of the FRCM/concrete bond behavior is required to maximize its potential use in $\mathrm{RC}$ strengthening $[1,8]$. Therefore, some research efforts have been dedicated in the past few years for that purpose [1823].
In view of this, the current paper has the following objectives: (a) to investigate the bond behavior between the FRCM composite and concrete substrate while using different FRCM systems; (b) to provide more insight into the effect of the bond length on the bond behavior of the FRCM/concrete interface. In this effort, as part of a larger scope ongoing efforts, three types of FRCM systems have been preliminary assessed; namely, glass-, carbon-, and polyparaphenylene benzobisoxazole (PBO)-FRCM. To achieve this, the double-lap direct shear test was performed on six concrete cubes externally-bonded with FRCM systems, with the consideration of FRCM type and bond length as test variables.

The experimental program will first be explained in terms of materials description, test specimens, and test setup. After that, results and observations of the experiments will be presented and discussed, mainly for the failure mode and the bond capacity of the FRCM systems adopted.

\section{Materials and methods}

A total of six concrete cubes of a side length of $150 \mathrm{~mm}$ were cast using ready-mix concrete with an average 28day compressive strength of $30 \mathrm{MPa}$. For each cube, FRCM system was applied on the opposite sides of the concrete substrate to create a double-shear connection as shown in Figure 1. Three types of commercially available

\footnotetext{
* Corresponding author: adel.younis@qu.edu.qa
} 
FRCM systems were considered, namely, glass-FRCM [24], carbon-FRCM [25], and PBO-FRCM [26].

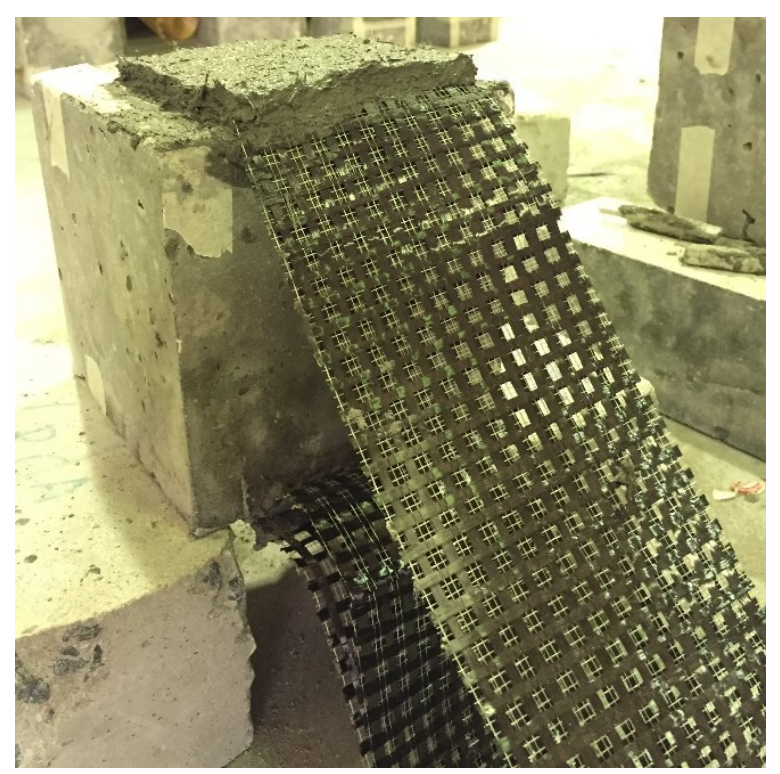

Fig. 1. Test specimen with an FRCM double-shear connection.

Each FRCM system was prepared as per the manufacturers' recommendations by embedding the fabrics in their corresponding mortar mixtures. Water was mixed -per $25 \mathrm{~kg}$ of mortar- with an amount of 5 litres for the glass-FRCM system and 7 litres for both carbon- and PBO-FRCM counterparts. Figure 2 and Table 1 show the geometric and mechanical properties for each fabric type as provided by the manufacturers [24-26].

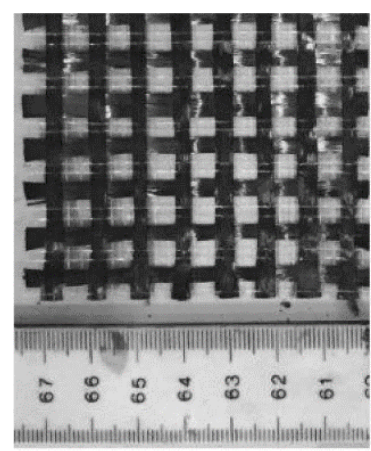

(a)

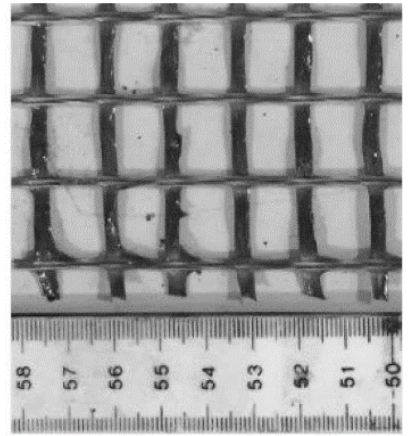

(b)

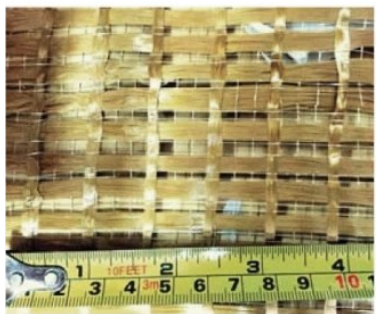

(c)

Fig. 2. Geometric properties of (a) carbon, (b) glass, and (c) PBO fabric.

These properties include the textile area per unit width $\left(A_{f}\right)$, ultimate strain $\left(\varepsilon_{u}\right)$, elastic modulus $(E)$, and tensile strength $\left(\sigma_{f u}\right)$, along with the compressive strength of their associated mortars $\left(f_{c}\right)$.
Table 1. Textile and mortar properties for the FRCM systems.

\begin{tabular}{|c|c|c|c|c|c|}
\hline $\begin{array}{c}\text { Textile } \\
\text { type }\end{array}$ & $\begin{array}{c}\boldsymbol{A}_{\boldsymbol{f}} \\
\left(\mathbf{m m}^{\mathbf{2}} / \mathbf{m m}\right)\end{array}$ & $\begin{array}{c}\mathbf{E} \\
(\mathbf{G P a})\end{array}$ & $\begin{array}{c}\boldsymbol{\sigma}_{\boldsymbol{f u}} \\
(\mathbf{G P a})\end{array}$ & $\begin{array}{c}\boldsymbol{\varepsilon}_{\boldsymbol{u}} \\
\mathbf{( \% )}\end{array}$ & $\begin{array}{c}\boldsymbol{f}_{\boldsymbol{c}} \\
(\mathbf{M P a})\end{array}$ \\
\hline PBO & 0.045 & 270 & 5.80 & 2.15 & 30 \\
\hline Carbon & 0.047 & 240 & 4.80 & 1.80 & 20 \\
\hline Glass & 0.047 & 80 & 2.60 & 3.25 & 40 \\
\hline
\end{tabular}

To achieve a profound investigation on the $\mathrm{FRCM} /$ concrete bond behavior, the uniaxial tensile characterization of the overall FRCM composite is required. This will corroborate the current study with sufficient knowledge about the behavior of FRCM systems as individually subjected to a uniaxial tensile load, allowing for a more justifiable interpretation for the results of FRCM systems while bonded to the concrete surface. In view of that, Table 2 lists the tensile characterization test results for each FRCM type, obtained elsewhere by the authors [15]. The table includes the mean ultimate strain $\left(\varepsilon_{F R C M, u}\right)$, tensile strength $\left(\sigma_{F R C M, u}\right)$, cracked tensile modulus of elasticity $\left(E_{F R C M}\right)$, and failure mode for the FRCM systems. As shown in the table, the glass-FRCM system exhibited a more brittle failure mode as well as lower mechanical properties than those observed for the carbon-FRCM and PBO-FRCM counterparts.

Table 2. Summary of the tensile characteristics of the FRCM systems adopted [15].

\begin{tabular}{|c|c|c|c|c|}
\hline FRCM system & $\begin{array}{c}\boldsymbol{\sigma}_{\boldsymbol{F R C M , u}} \\
(\mathbf{M P a})\end{array}$ & $\begin{array}{c}\boldsymbol{\varepsilon}_{\boldsymbol{F R C M}, \boldsymbol{u}} \\
(\%)\end{array}$ & $\begin{array}{c}\boldsymbol{E}_{\boldsymbol{F R C M}} \\
(\mathbf{G P a})\end{array}$ & $\begin{array}{c}\text { Failure } \\
\text { mode* }^{*}\end{array}$ \\
\hline Glass-FRCM & 767 & 0.93 & 60 & FR \\
\hline PBO-FRCM & 1235 & 1.06 & 112 & FS \\
\hline Carbon-FRCM & 1178 & 1.04 & 135 & FS \\
\hline
\end{tabular}

${ }^{*} \mathrm{FS}=$ Fabric Slippage; FR = Fabric Rupture

The FRCM composite typically included a single layer of fabric, and was applied with a uniform bond width of $100 \mathrm{~mm}$ for all test specimens. Two test variables were considered: (a) FRCM material (glass, carbon, and PBO); and (b) bond length $(75$ or $100 \mathrm{~mm})$. Table 3 shows the characteristics of the specimens used in this study.

Table 3. Characteristics of the test specimens.

\begin{tabular}{|c|c|c|}
\hline Designation & $\begin{array}{c}\text { Fabric } \\
\text { material }\end{array}$ & $\begin{array}{c}\text { Bond } \\
\text { length }(\mathbf{m m})\end{array}$ \\
\hline C-L75 & Carbon & 75 \\
\hline C-L100 & Carbon & 100 \\
\hline P-L75 & PBO & 75 \\
\hline P-L100 & PBO & 100 \\
\hline G-L75 & Glass & 75 \\
\hline G-L100 & Glass & 100 \\
\hline
\end{tabular}

Figure 3 illustrates the setup and instrumentation for the double-lap shear test performed on the FRCM-bonded concrete cubes. The FRCM composite was axially loaded, 
simultaneously from both sides of the specimen, by stretching the fabric using a hydraulic jack with a manual pump operated at an approximate rate of $4 \mathrm{~mm} / \mathrm{min}$. A curved-edges steel plate was placed between the hydraulic jack and the top end of the stretched fabric to allow a uniform distribution of the load throughout the fabric mesh. This mitigated the stress concentration at the fabric edges and reduced the likelihood of a premature fabric rupture. A cylindrical load cell of $500-\mathrm{kN}$ capacity was installed between the hydraulic jack and the test specimen to continuously control the load applied during the test. Also, the slip of the FRCM composite was continuously measured using a linear variable displacement transducer (LVDT). The test set-up was connected to a data acquisition system to store the measured values.

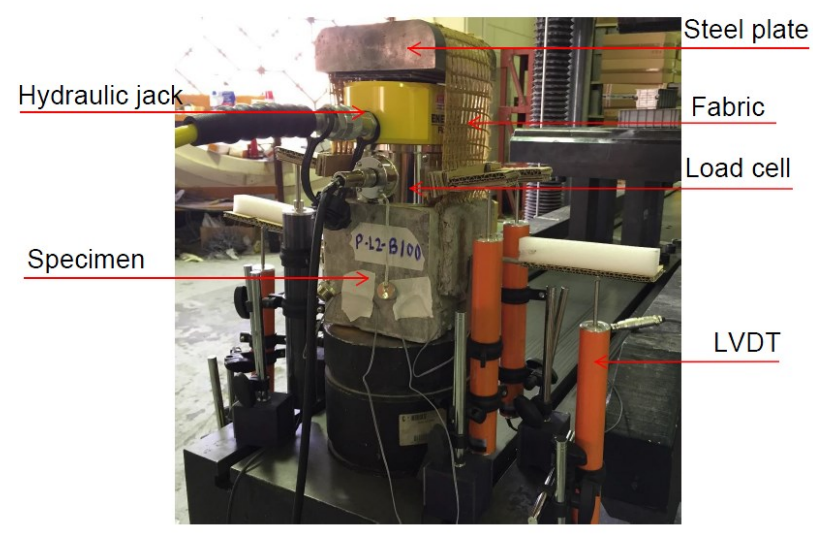

Fig. 3. Test setup for the double-lap direct shear test.

\section{Results and discussions}

Table 4. Summary of the test results.

\begin{tabular}{|c|c|c|c|c|}
\hline Specimen ID & $\begin{array}{c}P_{u} \\
(\mathbf{k N})\end{array}$ & $\begin{array}{c}\tau_{u} \\
(\mathbf{k P a})\end{array}$ & $\underset{(\mathbf{m m})}{\delta_{u}}$ & $\begin{array}{l}\text { Failure } \\
\text { mode }\end{array}$ \\
\hline C-L75 & 3.34 & 222 & 4.2 & FD \\
\hline C-L100 & 6.48 & 324 & 5.5 & FD \\
\hline P-L75 & 7.85 & 523 & $\approx$ zero & DB \\
\hline P-L100 & 10.75 & 538 & 0.03 & DB \\
\hline G-L75 & 3.38 & 225 & 0.03 & FR \\
\hline G-L100 & 6.11 & 305 & 0.09 & FR \\
\hline
\end{tabular}

*FD: Fabric delamination (associated with fabric elongation and slippage); DB: Debonding at the concrete/matrix interface; FR: Fabric rapture.

Table 4 presents a summary of the test results. For each specimen, the second and the third columns of Table 4 list the failure load $\left(P_{u}\right)$ and its corresponding ultimate shear stress $\left(\tau_{u}\right)$, respectively. The FRCM slip measured at failure $\left(\delta_{u}\right)$ and the modes of failure are listed in the fourth and fifth columns of Table 4 , respectively. The ultimate shear stress $\left(\tau_{u}\right)$ was calculated as the failure load $\left(P_{u}\right)$ divided by the total FRCM bonded area as follows:

$$
\tau_{u}=\frac{P_{u}}{2 L_{b} W_{b}}
$$

where $L_{b}$ is the FRCM bonded length and $W_{b}$ is the FRCM bond width.

The concrete/FRCM bond capacity was higher in the case of PBO-FRCM system than that of glass- and carbon-FRCM counterparts. The average shear-stress capacity of the FRCM/concrete bond for PBO-, carbon-, and glass-FRCM systems was 530, 273, and $265 \mathrm{kPa}$, respectively. As intuitively expected, increasing the bond length has generally led to a significant improvement in the FRCM/concrete bond capacity. The average gain achieved in the FRCM/concrete bond capacity due to increasing the bond length by $33 \%$ was 94,37 , and $81 \%$ for carbon-, PBO-, and glass-FRCM systems, respectively. The significance of FRCM/concrete bond length was also indicated in previous research contributions [20,22,23].

In general, the carbon-FRCM system exhibited fabric delamination within the fabric/matrix interface (FD) at failure, preceded by fabric elongation and slippage during the load application (Figure 4-a). The PBO-FRCM system, however, showed debonding at the matrix/concrete interface (DB) at failure (Figure 4-b). The failure mode for the glass-FRCM system was generally a premature rupture of the stretched fabric (FR) (Figure 4c). Therefore, the bond failure was more brittle in the case of glass- and PBO-FRCM systems than that of the carbonFRCM counterpart. This can be further evidenced by the following observations: (i) the lower values of FRCM slip measured at failure $\left(\delta_{u}\right)$ in the case of PBO- and glassFRCM systems compared to those of carbon-FRCM counterpart (Table 4); and (ii) the sudden drop observed at failure in the curve of load versus displacement in the case of glass- and PBO-FRCM systems (Figure 5).

The FR failure mode exhibited by the glass-FRCM system can be attributed to the inherent lower mechanical properties of glass fibres compared to those of PBO and carbon counterparts (Table 1). This can also be linked to the FR failure mode exhibited by the glass-FRCM composite under uniaxial load (Table 2).

Given the comparable mechanical properties of their fabric strands, the discrepancy in the bond failure between carbon- and PBO-FRCM systems can be explained in view of the fabric geometry. As shown in Figure 2, the effectual fabric of carbon-FRCM system exists in two directions. The PBO fabrics, however, are more effective in the warp direction, with more spacing realized between the fabric strands in the weft direction. Therefore, the twoway fabric sheet in carbon-FRCM resulted in a lower bond between fabric and mortar within the FRCM composite due to the less mortar penetration throughout the fabric layer and thus less mechanical interlock. On the other hand, the fabric/matrix interface was stronger in the PBO uniaxial textile and thus leading the failure to rather occur in the bond between the FRCM matrix and concrete substrate. The effect of the fabric geometry on the FRCM/concrete bond behavior was also indicated by previous researchers $[8,18]$. 


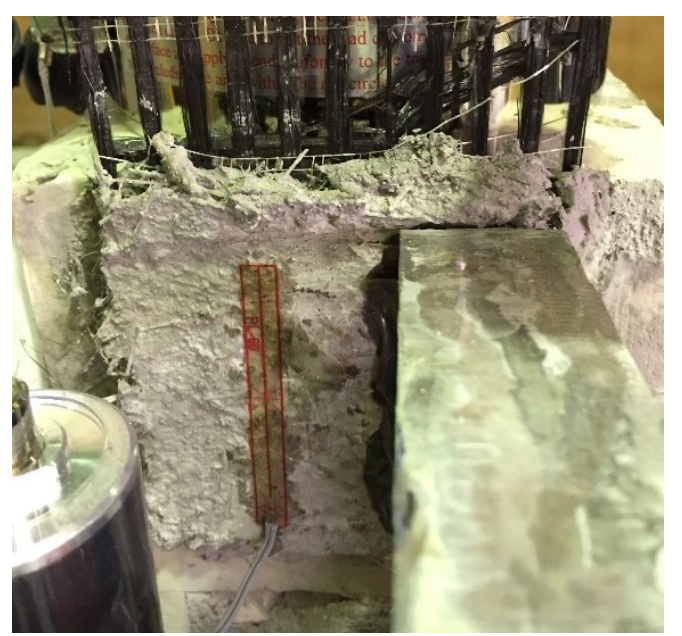

(a)

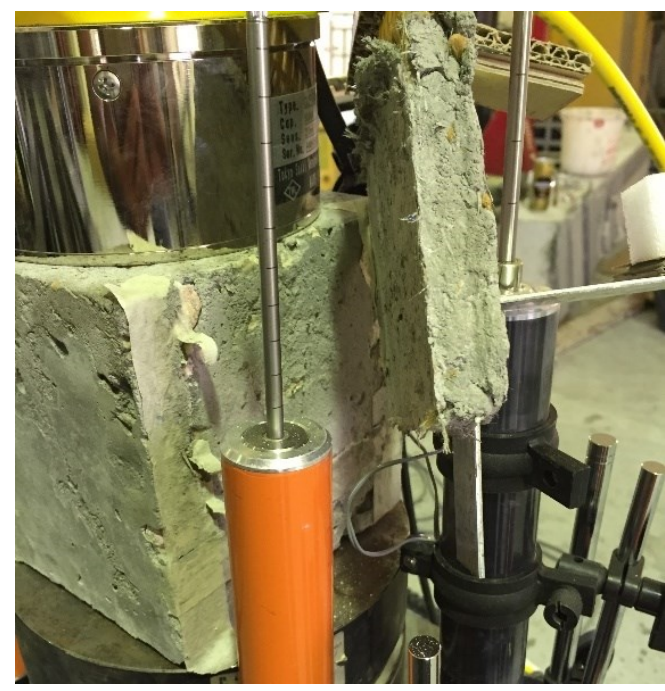

(b)

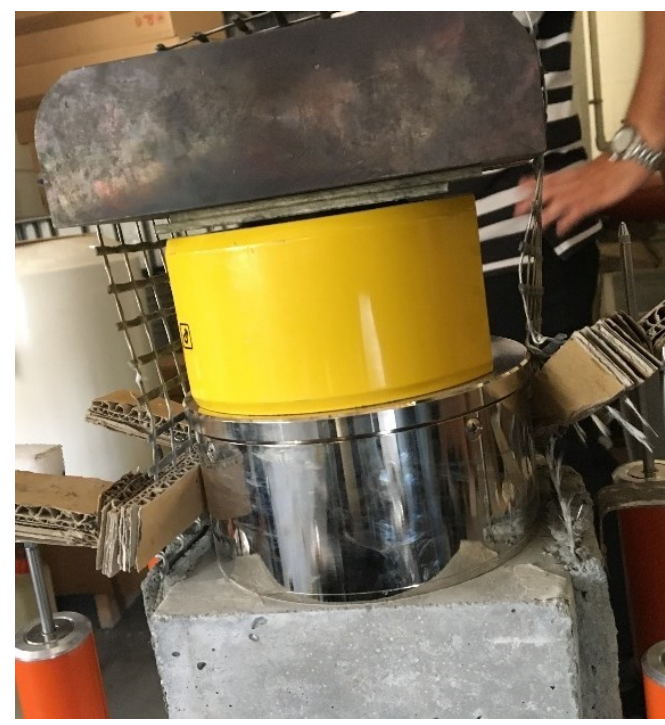

(c)

Fig. 4. Failure mode observed: (a) FD in carbon-FRCM system; (b) DB in PBO-FRCM system; and (c) FR in glass-FRCM system.

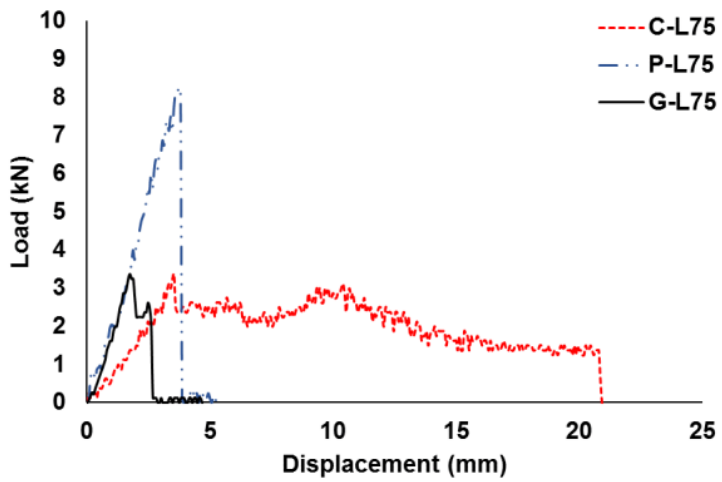

Fig. 5. Load-displacement diagram for different FRCM systems.

\section{Conclusions}

This paper has investigated the FRCM/concrete bond characteristics for different FRCM systems. Three FRCM systems were considered, namely, carbon-FRCM, glassFRCM, and PBO-FRCM. A total of six concrete cubes of $150-\mathrm{mm}$ size were cast and externally-bonded with FRCM system from two opposite sides to prepare for the double-lap direct shear loading test. Two test variables were considered, namely, the FRCM material and the bond length. Based on the study results, the following conclusions have been drawn:

- The PBO-FRCM system exhibited a stronger bond capacity between the FRCM layer and concrete substrate. The shear-stress capacity of the FRCM/concrete interface was approximately double that of carbon- and glass-FRCM counterparts.

- The modes of failure observed at the FRCM/concrete bond are fabric delamination for carbon-FRCM, debonding at the $\mathrm{FRCM} /$ concrete interface for the PBO-FRCM, and premature fabric rupture for glassFRCM systems.

- The failure of the FRCM/concrete bond was more ductile with a higher FRCM slip in the case of carbonFRCM system as compared to that of glass- and PBOFRCM counterparts.

- The bond length has a significant effect on the FRCM/concrete bond capacity. For instance, increasing the bond length from 75 to $100 \mathrm{~mm}$ has led to an improvement reaching $100 \%$ in the carbonFRCM/concrete bond capacity.

This paper was made possible by grant \# QUST-CENG-SPR14/15-16 from Qatar University. The findings achieved herein are solely the responsibility of the authors.

\section{References}

1. Shrestha, K. C.; Ebead, U.; Younis, A. Effect of Surface Roughening on Concrete/TRM Bond. In Proceedings of the Ninth International Structural Engineering and Construction Conference, Resilient Structures and Sustainable Construction; ISEC Press: Valencia, Spain, 2017; p. St-43.

2. Ebead, U. Inexpensive Strengthening Technique for 
Partially Loaded Reinforced Concrete Beams : Experimental Study. J. Mater. Civ. Eng. 2015, 11, 111, doi:10.1061/(ASCE)MT.1943-5533.0001249.

3. Baky, H. A.; Ebead, U. A.; Neale, K. W. Flexural and interfacial behavior of FRP-strengthened reinforced concrete beams. J. Compos. Constr. 2007, 11, 629639.

4. Ebead, U. Hybrid externally bonded/mechanically fastened fiber-reinforced polymer for $\mathrm{RC}$ beam strengthening. ACI Struct. J. 2011, 108, 669.

5. Elsayed, W. E.; Ebead, U. A.; Neale, K. W. Mechanically fastened FRP-strengthened two-way concrete slabs with and without cutouts. J. Compos. Constr. 2009, 13, 198-207.

6. Ebead, U. A.; Saeed, H. Flexural and Interfacial Behavior of Externally Bonded/Mechanically Fastened Fiber-Reinforced Polymer Strengthened Reinforced Concrete Beams. ACI Struct. J. 2014, 111, 741-752.

7. Younis, A.; Ebead, U. A.; Nanni, A. A Perspective on Seawater/FRP Reinforcement in Concrete Structures. In Proceedings of the Ninth International Structural Engineering and Construction Conference, Resilient Structures and Sustainable Construction; ISEC Press: Valencia, Spain, 2017; p. St-38.

8. Awani, O.; El-Maaddawy, T.; Ismail, N. Fabricreinforced cementitious matrix: A promising strengthening technique for concrete structures. Constr. Build. Mater. 2017, 132, 94-111.

9. Loreto, G.; Leardini, L.; Arboleda, D.; Nanni, A. Performance of RC slab-type elements strengthened with fabric-reinforced cementitious-matrix composites. J. Compos. Constr. 2013, 18, A4013003.

10. Ombres, L.; Verre, S. Structural behaviour of fabric reinforced cementitious matrix (FRCM) strengthened concrete columns under eccentric loading. Compos. Part B Eng. 2015, 75, 235-249.

11. Ombres, L. Concrete confinement with a cement based high strength composite material. Compos. Struct. 2014, 109, 294-304.

12. Ebead, U.; Shrestha, K. C.; Afzal, M. S.; El Refai, A.; Nanni, A. Effectiveness of fabric-reinforced cementitious matrix in strengthening reinforced concrete beams. J. Compos. Constr. 2017, 21, 4016084.

13. Elghazy, M.; El Refai, A.; Ebead, U. A.; Nanni, A. Effect of corrosion damage on the flexural performance of RC beams strengthened with FRCM composites. Compos. Struct. 2017, 180, doi:10.1016/j.compstruct.2017.08.069.

14. Loreto, G.; Babaeidarabad, S.; Leardini, L.; Nanni, A. RC beams shear-strengthened with fabricreinforced-cementitious-matrix (FRCM) composite. Int. J. Adv. Struct. Eng. 2015, 7, 341-352.
15. Younis, A.; Ebead, U.; Shrestha, K. C. Different FRCM systems for shear-strengthening of reinforced concrete beams. Constr. Build. Mater. 2017, 153, 514-526, doi:10.1016/j.conbuildmat.2017.07.132.

16. Wakjira, T. G.; Ebead, U. Hybrid NSE/EB technique for shear strengthening of reinforced concrete beams using FRCM: Experimental study. Constr. Build. Mater. 2018, 164, 164-177, doi:10.1016/j.conbuildmat.2017.12.224.

17. Younis, A.; Ebead, U. A.; Shrestha, K. C. FRCM Shear Strengthening for Concrete Beams. In Proceedings of the Ninth International Structural Engineering and Construction Conference, Resilient Structures and Sustainable Construction; ISEC Press: Valencia, Spain, 2017; p. St-27.

18. Hashemi, S.; Al-Mahaidi, R. Investigation of bond strength and flexural behaviour of FRP-strengthened reinforced concrete beams using cement-based adhesives. Aust. J. Struct. Eng. 2010, 11, 129-139, doi:http://dx.doi.org/10.1080/13287982.2010.11465 061 .

19. Sneed, L. H.; D’Antino, T.; Carloni, C.; Pellegrino, C. A comparison of the bond behavior of PBOFRCM composites determined by double-lap and single-lap shear tests. Cem. Concr. Compos. 2015, 64, 37-48, doi:10.1016/j.cemconcomp.2015.07.007.

20. D'Ambrisi, A.; Feo, L.; Focacci, F. Experimental analysis on bond between PBO-FRCM strengthening materials and concrete. Compos. Part B Eng. 2013, 44 , $524-532$, doi:10.1016/j.compositesb.2012.03.011.

21. Ombres, L. Analysis of the bond between Fabric Reinforced Cementitious Mortar (FRCM) strengthening systems and concrete. Compos. Part B Eng. 2015, 69, 418-426, doi:10.1016/j.compositesb.2014.10.027.

22. Raoof, S. M.; Koutas, L. N.; Bournas, D. A. Bond between textile-reinforced mortar (TRM) and concrete substrates: Experimental investigation. Compos. Part B Eng. 2016, 98, 350-361, doi:10.1016/j.compositesb.2016.05.041.

23. Awani, O.; Refai, A. El; El-Maaddawy, T. Bond characteristics of carbon fabric-reinforced cementitious matrix in double shear tests. Constr. Build. Mater. 2015, 101, 39-49, doi:10.1016/j.conbuildmat.2015.10.017.

24. SIKA Technical datasheet, SikaWrap-350G Grid data sheet.; 2016;

25. Ruredil Technical datasheet, Ruredil X mesh C10 data sheet.; 2016;

26. Ruredil Technical datasheet, Ruredil X mesh gold data sheet.; 2016; 